\title{
Passive Samplers Deployment in the Ayapel Swamp for Monitoring Temporal Dynamics of Mercury in the Water Column
}

\author{
Diego Orlando Murillo, Daniel Esteban León, Claudio Jiménez* \\ Faculty of Engineering, Lasallian University, Caldas, Colombia \\ Email: *clajimenez@lasallistadocentes.edu.co
}

How to cite this paper: Murillo, D.O., León, D.E. and Jiménez, C. (2017) Passive Samplers Deployment in the Ayapel Swamp for Monitoring Temporal Dynamics of Mercury in the Water Column. Journal of Water Resource and Protection, 9, 873-880. https://doi.org/10.4236/jwarp.2017.98058

Received: January 25, 2017

Accepted: June 30, 2017

Published: July 3, 2017

Copyright $\odot 2017$ by authors and Scientific Research Publishing Inc. This work is licensed under the Creative Commons Attribution International License (CC BY 4.0).

http://creativecommons.org/licenses/by/4.0/

\begin{abstract}
Passive sampling is a simple and efficacious sampling technique that guarantees a safe collection and transportation of samples to the analysis site, and obtaining results with more temporal resolution. As a case of study, passive samplers were deployed in the Ayapel Swamp, Colombia, located in the influence zone of open pit gold mines. Mercury, iron and manganese were sampled at two different depths by the Chemcatcher ${ }^{\circledast}$ passive sampler and regular grab sampling. Additionally, dissolved oxygen, oxidation-reduction potential, $\mathrm{pH}$ and water temperature were measured. The results showed that depth and time did not have a significant influence (ANOVA, confidence level of 95\%) on mercury concentration on both passive samplers and grab sampling. However, concentration of $\mathrm{Fe}$ and $\mathrm{Hg}$ in passive samplers had a high positive correlation, but it may be because depth increase during sampling period caused the dilution of both analytes. In conclusion, passive samplers proved to be a valuable tool for understanding the response of mercury to the Ayapel Swamp dynamics.
\end{abstract}

\section{Keywords}

Passive Sampling, Water Quality Monitoring, Water Column, Mercury, Iron, Manganese

\section{Introduction}

Metals can occur in water due to natural or anthropogenic activities [1] [2]. They occur as: dissolved metals, salts, organometals and adhere to colloid or particles. Some metals, like bioavailable $\mathrm{Cd}$ and $\mathrm{Pb}$, are toxic for living organisms even in very low concentrations [3].

Mercury and its compounds are recognized as a hazardous pollutant because 
they are persistent, bioaccumulative and toxic for human beings and the environment [4]. Consumption of aquatic organism is particularly dangerous for human health because MeHg bioaccumulates through the food chain [5] [6].

However, detection of mercury in water samples is not easy because of its low concentration. In addition, some environmental variables, such as $\mathrm{pH}$, temperature, ORP, microbial activity and sulfide contents, have influence in the speciation of Hg [7], which makes it a dynamic analyte in the water column. This situation creates the need to use a method capable of detecting mercury at very low concentrations and also gives more information about changes in that concentration during different environmental conditions.

Passive sampling is a technique suitable for detecting contaminant in trace concentration. Moreover, passive samplers' results represent a Time Weighted Average (TWA) concentration during the deployment time, which allows understanding the general state of the sampling site and analyzing changes produced between samplings with more temporal resolution and stabilizing the analyte prior the analysis [8].

The purpose of this research was the assessment of passive sampling as an alternative to monitor mercury concentrations in the Ayapel Swamp and understand its dynamics in time and depth. Chemcatcher ${ }^{\circledR}$ passive samplers were deployed at two depths during five sampling periods between $17^{\text {th }}$ September to $3^{\text {rd }}$ December, 2015. Grab samples were also taken to compare with the passive sampler results. Dissolved oxygen, ORP, $\mathrm{pH}$ and water temperature were also measured.

\section{Materials and Methods}

\subsection{Study Site}

The Ayapel Swamp is located in the department of Córdoba, in northwestern Colombia $\left(8^{\circ} 17^{\prime}-8^{\circ} 24^{\prime} \mathrm{N}\right.$ and $\left.75^{\circ} 4^{\prime}-75^{\circ} 9^{\prime} \mathrm{W}\right)$, at $25 \mathrm{~m}$ above sea level. It is part of the wetland system and floodplains of the Depresión Momposina. The Ayapel Swamp has an area of 40,000 hectares in the rainy season and 15,000 hectares in the dry season. The Swamp's tributaries carry gold mining residues with a big charge of mercury. Occasionally, even Cauca River, which is one of the most impacted rivers in Colombia by gold mining, delivers water to the Ayapel Swamp. Once mercury enters the Swamp's system, it becomes biogeochemically complex. Therefore, several studies have been made in this site. It has been found mercury in plants, fishes, jaguar teeth and human hair [9]. This situation poses a threat to human health because the Swamp serves as a source of drinking water and fishery products. It is also a danger for the large amount of fauna and flora that lives in the Swamp.

The sampling site was Mi Ranchito Bay $\left(08^{\circ} 19^{\prime} 07.8^{\prime \prime} \mathrm{N}\right.$ and $\left.075^{\circ} 08^{\prime} 14.8^{\prime \prime} \mathrm{W}\right)$, located near the urban center of the municipality of Ayapel. It is a shallow place, where depths varied from $148 \mathrm{~cm}$ at the beginning of the sampling campaign to $214 \mathrm{~cm}$ at the end of the sampling campaign. Ayapel Swamp and the sampling site is shown in Figure 1. 


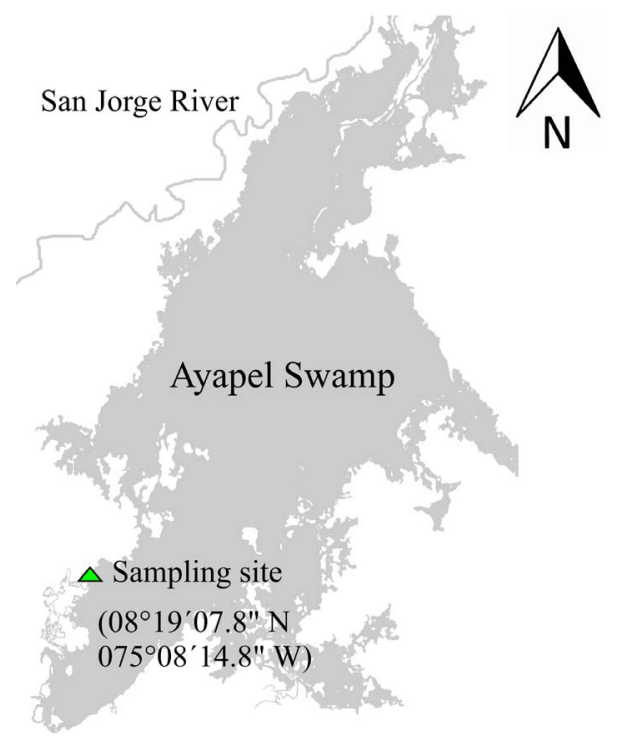

Figure 1. Sampling site location.

\subsection{Passive Samplers}

Chemcatcher ${ }^{\oplus}$ passive samplers were used in this study. This passive sampler has been described previously by [10]. The device is made of PTFE and it supports an Empore chelating disk ( $47 \mathrm{~mm}$ diameter, $0.5 \mathrm{~mm}$ thickness), which is the receiving phase where analytes are accumulated. The disks were placed in a vacuum filtration system and washed with ultrapure water $(20 \mathrm{~mL})$ and $\mathrm{HNO}_{3}(3$ $\left.\mathrm{mol} \cdot \mathrm{L}^{-1}, 20 \mathrm{~mL}\right)$. Then they were rinsed with ultrapure water $(50 \mathrm{~mL} \times 2)$, followed by addition of $100 \mathrm{~mL}$ of ammonium acetate buffer $\left(\mathrm{pH} 5.3,0.1 \mathrm{~mol} \cdot \mathrm{L}^{-1}\right)$. Finally, they were washed with ultrapure water $(20 \mathrm{~mL} \times 3)$. A cellulose acetate diffusion membrane was placed on the top of the receiving phase. They were previously immersed in $1 \% \mathrm{HNO}_{3}$ for 30 minutes to remove any contamination by metals and then rinsed with ultrapure water.

\subsection{Passive Samplers}

Chemcatcher ${ }^{\circledast}$ passive samplers were used in this study. This passive sampler has been described previously by [10]. The device is made of PTFE and it supports an Empore chelating disk ( $47 \mathrm{~mm}$ diameter, $0.5 \mathrm{~mm}$ thickness), which is the receiving phase where analytes are accumulated. The disks were placed in a vacuum filtration system and washed with ultrapure water $(20 \mathrm{~mL})$ and $\mathrm{HNO}_{3}(3$ $\left.\mathrm{mol} \cdot \mathrm{L}^{-1}, 20 \mathrm{~mL}\right)$. Then they were rinsed with ultrapure water $(50 \mathrm{~mL} \times 2)$, followed by addition of $100 \mathrm{~mL}$ of ammonium acetate buffer $\left(\mathrm{pH} 5.3,0.1 \mathrm{~mol} \cdot \mathrm{L}^{-1}\right)$. Finally, they were washed with ultrapure water $(20 \mathrm{~mL} \times 3)$. A cellulose acetate diffusion membrane was placed on the top of the receiving phase. They were previously immersed in $1 \% \mathrm{HNO}_{3}$ for 30 minutes to remove any contamination by metals and then rinsed with ultrapure water.

\subsection{Sampling}

Passive samplers were deployed during five sampling periods between 11th Sep- 
tember to 3rd December, 2015. The deployed passive samplers were retrieved for analysis every 14 days (except the second sampling period that was 21 days) and changed for a new set of passive samplers. The retrieved passive samplers were filled with water from the swamp to keep the membranes wet and they were refrigerated until analysis. Two samplers were used as field blank in each sampling.

Two depths were chosen for the sampling, $50 \mathrm{~cm}$ (photic zone) and $100 \mathrm{~cm}$ (aphotic zone). Three samplers were placed in plastic cages in each depth by means of buoys, ropes and anchorage devices.

Duplicate water samples were taken with a plastic Kemmerer bottle in every deployment/retrieving campaign. Then, they were fixed with $150 \mu \mathrm{L}$ of $65 \%$ $\mathrm{HNO}_{3}$ and refrigerated until analysis. In order to make comparable the TWA provided by passive samplers during the sampling periods, the results for grab samples and the other variables were averaged between the beginning and end of every sampling period.

\subsection{Sample Analysis}

For the extraction of the analytes, the disks were placed in a vacuum filtration system and it was added three times $10 \mathrm{~mL}$ of $\mathrm{HNO}_{3}\left(3 \mathrm{~mol} \cdot \mathrm{L}^{-1}\right)$. Water samples were digested with $7 \mathrm{~mL} 65 \% \mathrm{HNO}_{3}$ and $1 \mathrm{~mL} \mathrm{H}_{2} \mathrm{O}_{2}$ in a high pressure and temperature microwave oven. Eluates and digested water samples were analyzed with Atomic Absorption Spectrometry.

\section{Results and Discussion}

Calculation of the concentration of metals with passive samplers is defined by the following equation:

$$
C_{W}=\frac{m_{D}-m_{0}}{R_{s} t}
$$

where, $C_{W}$ is the TWA concentration of the analyte in the water $\left(\mu \mathrm{g} \cdot \mathrm{L}^{-1}\right), \mathrm{m}_{\mathrm{D}}$ is the mass of analyte accumulated in the receiving phase $(\mu \mathrm{g}), m_{0}$ is the initial mass of analyte in the receiving phase $(\mu \mathrm{g}), R_{s}$ is the sampling rate $\left(\mathrm{L} \cdot \mathrm{d}^{-1}\right)$ and $t$ is the deployment time (d).

The sampling rate is calculated in a tank experiment at a fixed concentration of analyte $\left(C_{W}\right)$. In this experiment, a curve is obtained with the mass of analyte accumulated in the receiving phase on the $y$-axis and the sampler exposure time on the x-axis. $R_{s}$ is calculated by dividing the slope of the curve by the aqueous analyte concentration during the exposure period.

As can be seen in Table 1 , average HgGS is $1.061 \mu \mathrm{g} \cdot \mathrm{L}^{-1}$. It is above $1 \mu \mathrm{g} \cdot \mathrm{L}^{-1}$, which is the maximum allowable value for drinking water in Colombia by the resolution 2115 of 2007. Maximum allowable values for Fe and $\mathrm{Mn}$ are 300 and $100 \mu \mathrm{g} \cdot \mathrm{L}^{-1}$ respectively, which were also exceeded. This means that consumption of water from this site could represent a risk for human health.

Moreover, bioaccumulation of mercury through the food chain is a risk to the large amount of resident and migrant birds that feed from the swamp [11]. 
Table 1. Statistical summary of the variables measured in the Bahía Mi Ranchito, Ayapel Colombia.

\begin{tabular}{|c|c|c|c|c|c|c|c|c|c|c|}
\hline & $\begin{array}{c}\text { HgPS } \\
\left(\mu g \cdot L^{-1}\right)\end{array}$ & $\begin{array}{c}\mathrm{HgGS} \\
\left(\mu \mathrm{g} \cdot \mathrm{L}^{-1}\right)\end{array}$ & $\begin{array}{c}\text { FePS } \\
\left(\mu \mathrm{g} \cdot \mathrm{L}^{-1}\right)\end{array}$ & $\begin{array}{c}\text { FeGS } \\
\left(\mu \mathrm{g} \cdot \mathrm{L}^{-1}\right)\end{array}$ & $\begin{array}{c}\text { MnPS } \\
\left(\mu g \cdot L^{-1}\right)\end{array}$ & $\begin{array}{c}\text { MnGS } \\
\left(\mu \mathrm{g} \cdot \mathrm{L}^{-1}\right)\end{array}$ & $\begin{array}{c}\text { DO } \\
(\mathrm{mg} / \mathrm{L})\end{array}$ & $\mathrm{pH}$ & $\begin{array}{c}\mathrm{T} \\
\left({ }^{\circ} \mathrm{C}\right)\end{array}$ & $\begin{array}{l}\text { ORP } \\
(\mathrm{mV})\end{array}$ \\
\hline Mean & 0.226 & 1.061 & 326.396 & 1525.150 & 101.325 & 138.817 & 6.19 & 6.65 & 32.3 & 146.3 \\
\hline \pm & \pm & \pm & \pm & \pm & \pm & \pm & \pm & \pm & \pm & \pm \\
\hline sd & 0.570 & 1.022 & 451.41 & 876.973 & 107.075 & 31.158 & 1.32 & 0.41 & 0.8 & 81.7 \\
\hline $\mathrm{CV}$ & 252 & 96 & 138 & 58 & 106 & 22 & 21 & 6 & 2 & 56 \\
\hline
\end{tabular}

It was found by means of an ANOVA, with a confidence level of $95 \%$, that depth and sampling date did not have a significant influence on HgPS and HgGS. HgPS had a strong correlation $\left(\mathrm{r}^{2}=0.741\right)$ with FePS. Reference [12] also found a significant correlation between dissolved $\mathrm{Fe}$ and dissolved $\mathrm{Hg}$.

A possible explanation for the homogeneity of the concentration of $\mathrm{Hg}$ could be that the water column is mixed. However, the concentration of FePS was significantly greater in depth 2 (ANOVA, confidence level of 95\%), which means that the water column is not totally mixed. This also shows that there could be a reduction of Fe hydrous oxides in the sediments that represent a great source of $\mathrm{Fe}(\mathrm{II})$ [13], because passive samplers accumulate mainly the freely dissolved and kinetically labile unbound fraction of metals present in the water [10].

In several studies, variation of mercury in the water column was associated to the adsorption of mercury to oxyhydroxides of iron and manganese [14] and its sedimentation from the epilimnion and their dissolution in the anoxic hypolimnion [15]. In this study, dissolved oxygen was present in the entire water column during this experiment, which could be an explanation for the low variability of $\mathrm{Hg}$ in the water column. However, even with the presence of oxygen in the entire water column, $\mathrm{MeHg}$ concentration may increase with depth [16]. If there had been an increase in $\mathrm{MeHg}$ concentration, it would have been represented in a larger HgGS.

Photoreduction may play an important role in DGM production in the water column [17]. Photoreduction of $\mathrm{Hg}$ may be mediated by photoreduced $\mathrm{Fe}(\mathrm{II})$ and $\mathrm{Mn}$ (II) which could reduce $\mathrm{Hg}$ (II) when they reoxidize, as they are known to do for other elements [18]. Another mechanism for photoreduction may be associated to activity of photosynthetic phytoplankton and cyanobacteria [19]. $\mathrm{MeHg}$ also seems to be photodegrated in oxic waters [20]. A significant photoreduction activity would be reflected in a lower concentration in passive samplers because they do not accumulate $\mathrm{Hg}(0)$. Considering that calculations with passive samplers are TWA concentrations that included day and night periods, photoreduction did not seem to be representative in the long-term. Maybe, photoreduction is a mechanism important when concentrations of $\mathrm{Hg}$ are in the picomolar range [2]. In the picomolar range, DGM concentration can decrease more than $80 \%$ in the night [17].

However, $\mathrm{Hg}$ behavior can be explained by another variable. It is shown in Figure 2(a) that average depth increased during almost the entire sampling pe- 


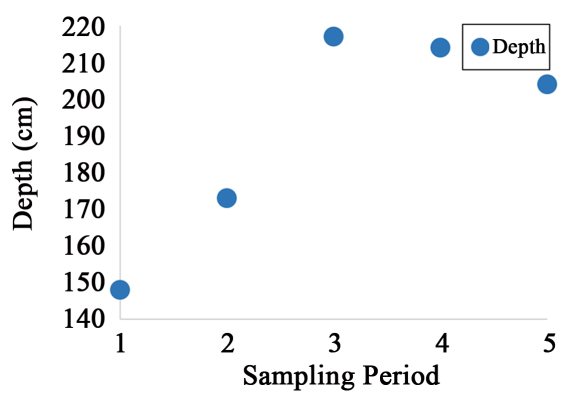

(a)

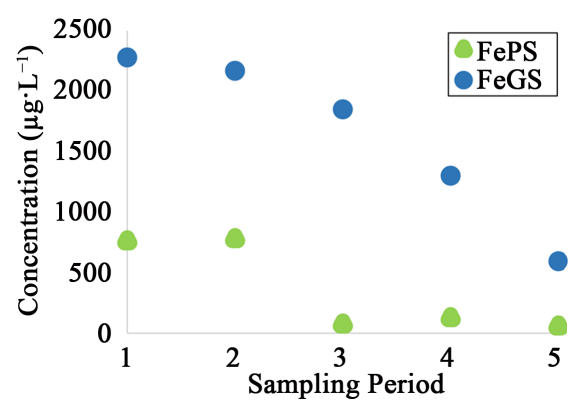

(c)

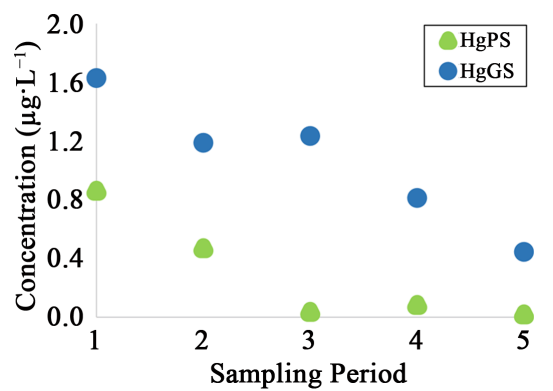

(b)

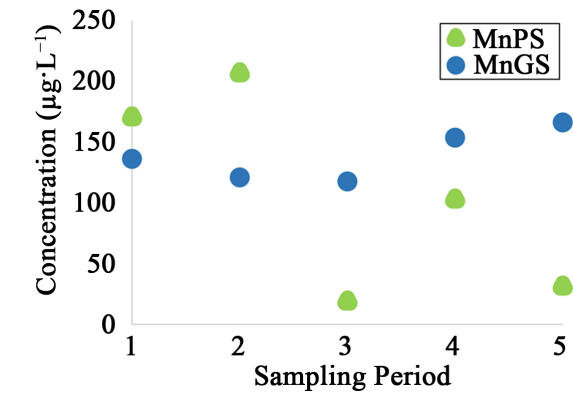

(d)

Figure 2. Average depth (a) and concentrations of $\mathrm{Hg}$ (b), Fe (c) and $\mathrm{Mn}$ (d) during sampling periods.

riod, whereas HgPS, HgGS, FePS and FeGS (B and C) decrease inversely proportional to depth. Given that the Bahía Mi Ranchito is shallow place, water income from water sources that fill The Ayapel Swamp between April and November dilutes analytes present in water.

Contrary to mercury, FePS was significantly different in depth and time. Additional to correlation with $\mathrm{HgPS}$, FePS has a high negative correlation with ORP $\left(r^{2}=-0.721\right)$ given that FePS is mainly composed by $\mathrm{Fe}(\mathrm{II})$, which is generated when ORP decreases. FePS also had a moderate correlation with MnPS $\left(\mathrm{r}^{2}\right.$ $=0.576)$. A higher correlation between Fe(II) and Mn(II) was found by [13]. This may reflect $\mathrm{Fe}$ and $\mathrm{Mn}$ hydrous oxides sedimentation and reduction in sediments as a source of $\mathrm{Fe}(\mathrm{II})$ and $\mathrm{Mn}(\mathrm{II})$ in the Bahía Mi Ranchito.

Even though $\mathrm{Hg}$ has proven to be dynamic in water and is prone to interact with biotic and abiotic variables, in this study mercury seemed to be rather constant in depth and time. Dissolved oxygen, ORP, $\mathrm{pH}$ and water temperature were not related to mercury. However, the depth increase of the swamp that occurs from April to November appears to be more influential in average concentration of $\mathrm{Hg}$ due to dilution. HgPS had a correlation with FePS, but it may be because they both decreased when depth increased. On the other hand, Mn did not seem to have an influence in mercury dynamics.

\section{Conclusion}

Passive sampling was proven to be a valuable tool to generate information with more temporal resolution, which is important in aquatic systems subject to constant changes. TWA concentrations given by passive samplers are a good indi- 
cator of the general condition of the water and its quality during a defined period. Therefore, important information was generated about mercury dynamics in the water column and its response to the Ayapel Swamp depth changes and environmental variables.

\section{Acknowledgements}

We would like to thank the Fondo Nacional de Financiamiento para la Ciencia, la Tecnología y la Innovacion, Francisco José de Caldas (Colciencias) for funding the project with code 127556934788 . We appreciate the helpful comments of Dr. Néstor Aguirre and the logistic support of the GeoLimna group and CorpoAyapel.

\section{References}

[1] Mason, R.P. and Sheu, G.R. (2002) Role of the Ocean in the Global Mercury Cycle. Global Biogeochemical Cycles, 16, 40-1-40-14. https://doi.org/10.1029/2001gb001440

[2] Morel, F.M., Kraepiel, A.M. and Amyot, M. (1998) The Chemical Cycle and Bioaccumulation of Mercury. Annual Review of Ecology and Systematics, 29, 543-566. https://doi.org/10.1146/annurev.ecolsys.29.1.543

[3] Mills, G.A., et al. (2009) Monitoring Heavy Metals Using Passive Sampling Devices In: Rapid Chemical and Biological Techniques for Water Monitoring, John Wiley \& Sons, Ltd., 241-261. https://doi.org/10.1002/9780470745427.ch4a

[4] Selin, N.E. (2009) Global Biogeochemical Cycling of Mercury: A Review. Annual Review of Environment and Resources, 34, 43. https://doi.org/10.1146/annurev.environ.051308.084314

[5] Shastri, Y. and Diwekar, U. (2008) Optimal Control of Lake pH for Mercury Bioaccumulation Control. Ecological Modelling, 216, 1-17. https://doi.org/10.1016/j.ecolmodel.2008.03.019

[6] Mergler, D., et al. (2007) Methylmercury Exposure and Health Effects in Humans: A Worldwide Concern. AMBIO: A Journal of the Human Environment, 36, 3-11. https://doi.org/10.1579/0044-7447(2007)36[3:MEAHEI]2.0.CO;2

[7] Paraquetti, H.H.M., Ayres, G.A., De Almeida, M.D., Molisani, M.M. and De Lacerda, L.D. (2004) Mercury Distribution, Speciation and Flux in the Sepetiba Bay Tributaries, SE Brazil. Water Research, 38, 1439-1448.

https://doi.org/10.1016/j.watres.2003.11.039

[8] Fernández-Gómez, C., Hintelmann, H. and Díez, S. (2012). Passive Sampling for Inorganic Contaminants in Water. In: Pawliszyn, J., Ed., Comprehensive Sampling and Sample Preparation, Academic Press, Oxford, 281-296. https://doi.org/10.1016/b978-0-12-381373-2.00015-6

[9] Marrugo-Negrete, J., Benítez, L.N., Olivero-Verbel, J., Lans, E. and Gutierrez, F.V. (2010) Spatial and Seasonal Mercury Distribution in the Ayapel Marsh, Mojana Region, Colombia. International Journal of Environmental Health Research, 20, 451459. https://doi.org/10.1080/09603123.2010.499451

[10] Aguilar-Martínez, R., et al. (2009) Application of Chemcatcher Passive Sampler for Monitoring Levels of Mercury in Contaminated River Water. Talanta, 77, 14831489. https://doi.org/10.1016/j.talanta.2008.09.037

[11] Aguilera, M. (2009) Ciénaga de Ayapel: Riqueza en Biodiversidad y Recursos Hídricos. Banco de la República, Bogota. 
[12] Quémerais, B., Cossa, D., Rondeau, B., Pham, T. and Fortin, B. (1998) Mercury Distribution in Relation to Iron and Manganese in the Waters of the St. Lawrence River. Science of the Total Environment, 213, 193-201. https://doi.org/10.1016/S0048-9697(98)00092-8

[13] Chadwick, S.P., Babiarz, C.L., Hurley, J.P. and Armstrong, D.E. (2006) Influences of Iron, Manganese, and Dissolved Organic Carbon on the Hypolimnetic Cycling of Amended Mercury. Science of the Total Environment, 368, 177-188. https://doi.org/10.1016/j.scitotenv.2005.09.039

[14] Richard, J.H., Bischoff, C., Ahrens, C.G. and Biester, H. (2016) Mercury(II) Reduction and Co-Precipitation of Metallic Mercury on Hydrous Ferric Oxide in Contaminated Groundwater. Science of the Total Environment, 539, 36-44. https://doi.org/10.1016/j.scitotenv.2015.08.116

[15] Meili, M. (1997) Mercury in Lakes and Rivers. Metal Ions in Biological Systems, 34, 21-51.

[16] Sellers, P., Kelly, C.A. and Rudd, J.W. (2001) Fluxes of Methylmercury to the Water Column of a Drainage Lake: The Relative Importance of Internal and External Sources. Limnology and Oceanography, 46, 623-631. https://doi.org/10.4319/lo.2001.46.3.0623

[17] O’Driscoll, N.J., Beauchamp, S., Siciliano, S.D., Rencz, A.N. and Lean, D.R. (2003) Continuous Analysis of Dissolved Gaseous Mercury (DGM) and Mercury Flux in Two Freshwater Lakes in Kejimkujik Park, Nova Scotia: Evaluating Mercury Flux Models with Quantitative Data. Environmental Science \& Technology, 37, 22262235. https://doi.org/10.1021/es025944y

[18] Kaczynski, S.E. and Kieber, R.J. (1993) Aqueous Trivalent Chromium Photo Production in Natural Waters. Environmental Science \& Technology, 27, 1572-1576. https://doi.org/10.1021/es00045a011

[19] Barkay, T. and Wagner-Döbler, I. (2005) Microbial Transformations of Mercury: Potentials, Challenges, and Achievements in Controlling Mercury Toxicity in the Environment. Advances in Applied Microbiology, 57, 1-52. https://doi.org/10.1016/S0065-2164(05)57001-1

[20] Seller, P., Kelly, C., Rudd, J. and MacHutchon, A. (1996) Photodegradation of Methylmercury in Lakes. Nature, 380, 694-697. https://doi.org/10.1038/380694a0

\footnotetext{
Abbreviations

ANOVA $=$ Analysis of Variance.

DGM $=$ Dissolved gaseous mercury.

FePS $=$ Fe concentration in passive samplers.

$\mathrm{FeGS}=\mathrm{Fe}$ concentration in grab samples.

$\mathrm{HgPS}=\mathrm{Hg}$ concentration in passive samplers.

$\mathrm{HgGS}=\mathrm{Hg}$ concentration in grab samples.

$\mathrm{MeHg}=$ Methylmercury.

MnPS $=$ Mn concentration in passive samplers.

MnGS = Mn concentration in grab samples.

ORP $=$ Oxidation-reduction potential.

TWA $=$ Time-weighted average.
} 
Submit or recommend next manuscript to SCIRP and we will provide best service for you:

Accepting pre-submission inquiries through Email, Facebook, LinkedIn, Twitter, etc. A wide selection of journals (inclusive of 9 subjects, more than 200 journals)

Providing 24-hour high-quality service

User-friendly online submission system

Fair and swift peer-review system

Efficient typesetting and proofreading procedure

Display of the result of downloads and visits, as well as the number of cited articles Maximum dissemination of your research work

Submit your manuscript at: http://papersubmission.scirp.org/

Or contact jwarp@scirp.org 